\title{
Estimating flight ranges to unravel migratory strategies: spring migration of continental Black-tailed Godwits Limosa limosa limosa
}

\author{
JOSÉ A. ALVES and PEDRO M. LOURENÇO
}

\begin{abstract}
Summary
Mapping migratory routes and the distribution of species during migration requires information collected over large scales (e.g. survey data), or the ability to follow specific movements (e.g. using tracking devices), which is often limited to a few individuals. For endangered species, such techniques may be impractical, but developments in flight range modelling allow inferences about migratory routes and potential site occupancy, given a few morphological parameters. We modelled flight range in a rapidly declining population of continental Black-tailed Godwits Limosa limosa limosa departing from a staging site in Iberia during spring migration and found that the vast majority of godwits are able to reach the breeding grounds in a single flight. Contrary to the traditional use of staging sites in France (and Morocco), godwits currently staging in Iberia are predicted to fly directly to The Netherlands and be present at breeding locations earlier than previously expected and observed. Despite harbouring approximately $75 \%$ of the total population during spring migration, Iberian staging sites currently lack any legal protection. Our example of the Blacktailed Godwit illustrates the potential of this approach to identify migration strategies and locate staging sites for species of conservation concern for which such information may be virtually absent.
\end{abstract}

\section{Introduction}

Migratory species are likely to select their routes and migration strategies in order to reach their destination in the best condition possible and at the optimal time (Alerstam and Lindström 1990), but several factors can constrain their options. Crossing large barriers (e.g. mountain ranges, water-bodies, deserts), as well as the location of suitable habitats, often results in detours from the shortest route (Moreau 1972, Berthold 1993). For species that undertake long-distance non-stop flights, the maximum flight range can also be an important constraint. Flight range depends on wing characteristics, but also on the amount of fuel available, which is mainly stored as fat and, to a lesser extent, protein (Pennycuick 2008). If these parameters are known, flight range can now be predicted accurately (Alves et al. 2012). Although morphological parameters, such as wing shape, vary little among individual adults of the same species (Pennycuick 2008), the amount of fuel may show considerable individual variation, as it depends on migration strategy (e.g. long or short flight; Piersma 1987) and on resource availability and quality as well as foraging rates (Atkinson et al. 2007).

The distance an individual is able to cover in a single flight from a given starting point will determine whether it is able to arrive at its final migratory destination or needs to use further staging areas. Consequently, the estimation of flight ranges on a known route (i.e. heading) can be used to predict whether non-stop flights to a destination are possible, or whether additional 
staging is required and also predict the possible locations of such refuelling sites. Despite the advent of remote tracking technology that allows detailed tracking of individual migratory flights, the estimation of flight range can be a powerful tool to unravel migratory strategies for species that are either too small for such devices and/or that urgently need staging sites to be identified for conservation purposes.

In this study, we estimate the flight range of individuals from a rapidly declining population of Black-tailed Godwit Limosa limosa limosa during the final step of their northward migration between West Africa and The Netherlands. The western population of continental Black-tailed Godwits (hereafter, godwit) has declined by c.50\% since the 1980s (Birdlife International 2004). Agricultural intensification on the breeding grounds and habitat change at non-breeding sites have recently been identified as the most influential factors in the decline (Gill et al. 2007, Zwarts et al. 2009). In order to tackle this decline a list of key research gaps was identified, highlighting the need to improve the understanding of the location, timing and duration of use of passage sites in Europe (Iberia) and Africa (Gill et al. 2007). After staging in Iberia during spring migration, godwits leave for The Netherlands about two weeks before arriving at the breeding sites (Wymenga and Sikkema 2011). The location of a large portion of these individuals (38-44\%; Lourenço et al. 2010) during those weeks is currently uncertain (Kuijper et al. 2006), which prevents targeted conservation measures during this period of the annual cycle. The migratory flight (c.1,90o km) is estimated to be feasible in less than 30 hours, so the location of many godwits between leaving Iberia and reaching The Netherlands remains an unsolved issue (Lourenço et al. 2011). Two possible explanations have been suggested (Kuijper et al. 2006): (1) godwits stage in France en route to the Netherlands, but in small flocks with high levels of turnover, and/or in sites not covered during counts; (2) godwits move directly to The Netherlands but are missed early in the season. We use flight range models to estimate the proportion of godwits that are predicted to require further staging after departing from Iberia in order to investigate the likelihood of these two possibilities. We aim to investigate the potential use of sites by godwits during spring migration in order to target conservation measures for this population during this stage of the annual cycle.

\section{Methods}

\section{Sampling godwits departing from Iberia}

The vast majority of continental godwits migrate to core non-breeding areas in West Africa (Zwarts et al. 2009) before moving north to Iberia as early as December (Alves et al. 2010). In Iberia they make a prolonged stop-over between late December and early March (Lourenço et al. 2010), feeding almost entirely on rice-fields (Alves et al. 2010). Godwits were mist-netted in the rice-fields of Samora Correia $\left(38^{\circ} 56^{\prime} \mathrm{N}, 8^{\circ}{ }^{\circ} \mathrm{o}^{\prime} \mathrm{W}\right)$ in the vicinity of the Tagus estuary, just prior to departure, between 19 February and 4 March 2008-2010. In 2008, most godwits had left the rice-fields by 1 March (with a few staying until 7 March), and in 2009 and 2010 most had left by 27 February (P. Lourenço pers. obs.). All captured birds $(n=88)$ were weighed to the nearest gram and the exposed culmen, wing and tarsus length were measured to the nearest millimetre. For parameterisation of the flight model (see below), the wing spans of 29 individuals were measured to the nearest millimetre and tracings of wing shape were also taken in order to calculate wing area of 16 individuals, following Pennycuick (2008).

Godwits are sexually size dimorphic and females have duller breeding plumage than males (Shroeder et al. 2008). During staging in Iberia most individuals have moulted extensively into breeding plumage (P. Lourenço unpubl. data), hence sex was assigned based on plumage (resulting in bill lengths for all males $\leq 98.5 \mathrm{~mm}$ and all females $\geq 101 \mathrm{~mm}$ ). In addition, four individuals (one female and three males) were identified as juveniles based on plumage characteristics and were excluded from subsequent analysis because not all juveniles migrate to the breeding grounds (Zwarts et al. 2009). 


\section{Estimating flight range of Godwits departing from Iberia}

Flight program (Version 1.21; Pennycuick 2008) was used to model individual flight ranges from measurements of wing shape and body mass components. Average wing measurements were inputted separately for each sex given the significant differences in wing span $\left(U_{28}=30.5, Z=-3.17\right.$, $P<0.01)$ and wing area $\left(U_{15}=6.0, Z=-2.44, P=0.015\right.$; Table 1$)$. Flight muscle mass has previously been measured for godwits of the Icelandic subspecies Limosa limosa islandica in Iberia about to undertake the same migratory flight (from Portugal to The Netherlands; Alves et al. 2012) so we used the same values for continental godwits. The estimation of fat fraction (in relation to total body mass) was done following Pennycuick (2008) and, similarly to Alves (et al. 2012), by establishing a relationship between body mass and fat fraction using a large sample of body mass measurements for this population: 371 males and 349 females. Several model runs were executed with the heaviest individual in the sample (male $=364 \mathrm{~g}$, female $=404 \mathrm{~g}$ ) in order to test a range of values for fat fraction, attained from previously published studies (Alves et al. 2012). The relationship between body mass and fat fraction was established when the initial fat fraction considered from that range would allow the heaviest individual to terminate a simulated flight (i.e. without a set distance) with the body mass of the lightest individual ever recorded (male $=213 \mathrm{~g}$, female $=234 \mathrm{~g}$ ). Measurements of body mass were amassed from captures of breeding birds in The Netherlands (details in Shroeder et al. 2008) and departing birds captured in Iberia during this study, when both the heaviest male and female were recorded.

All simulations were run in Flight 1.2I (Pennycuick 2008) using default parameters as described by Alves (et al. 2012), with flight mode set to continuous flapping, speed control set to standard, departing altitude set at o $\mathrm{m}$ above sea level and cruising altitude set at 2,000 $\mathrm{m}$.

Distance between the departure location of the Tagus rice-fields and a core breeding location in the Netherlands, the Workumerwaard $\left(52^{\circ} 59^{\prime} \mathrm{N}, 5^{\circ} 25^{\prime} \mathrm{E}\right)$, was measured using the distance tool in Google Earth Version 5.I (earth.google.com), assuming that the flight route follows great circle lines. This breeding site was selected as $>100$ godwits colour-ringed there have been recorded staging on the Tagus rice-fields (Lourenço et al. 2011). The mapping of flight ranges was executed in ArcGIS 1o (ESRI).

\section{Results}

All females and almost every male godwit sampled had sufficient body mass to fly non-stop c.1,900 km or more and therefore to reach the breeding grounds in The Netherlands in one flight (Figure 1). The lightest female was estimated to be able to fly a total distance of $2,16 \mathrm{I} \mathrm{km}$, and approximately $90 \%$ of the males were also predicted to be able to reach the breeding site in a single flight (Figure 1). Of those lightest five males, only three (c.6\%) were estimated to be unable to reach the Netherlands. The remaining two (c. $4 \%$ ) were predicted to cover a total distance of c.1,750 km or more, which would equate to the northern area of the Dutch delta, an alternative breeding location. The lightest male was predicted to cover a total distance of c.1,350 km,

Table 1 . Wing, muscle and fat parameters of male and female continental Black-tailed Godwits used in Flight Version 1.21 to estimate flight range. Fat fraction is indicated for the heaviest individual.

\begin{tabular}{|c|c|c|c|c|c|c|}
\hline & \multicolumn{3}{|l|}{ Female } & \multicolumn{3}{|l|}{ Male } \\
\hline & Mean & SD & $\mathrm{N}$ & Mean & SD & $\mathrm{N}$ \\
\hline Wing span (m) & 0.726 & 0.021 & 12 & 0.699 & 0.013 & 17 \\
\hline Wing area $\left(\mathrm{m}^{2}\right)$ & 0.0767 & 0.0031 & 5 & 0.069 & 0.0046 & 11 \\
\hline Aspect ratio & 6.87 & - & - & 7.08 & - & - \\
\hline Muscle fraction & 0.206 & 0.005 & 3 & 0.214 & - & 1 \\
\hline Fat fraction & 0.306 & - & 1 & 0.300 & - & 1 \\
\hline
\end{tabular}




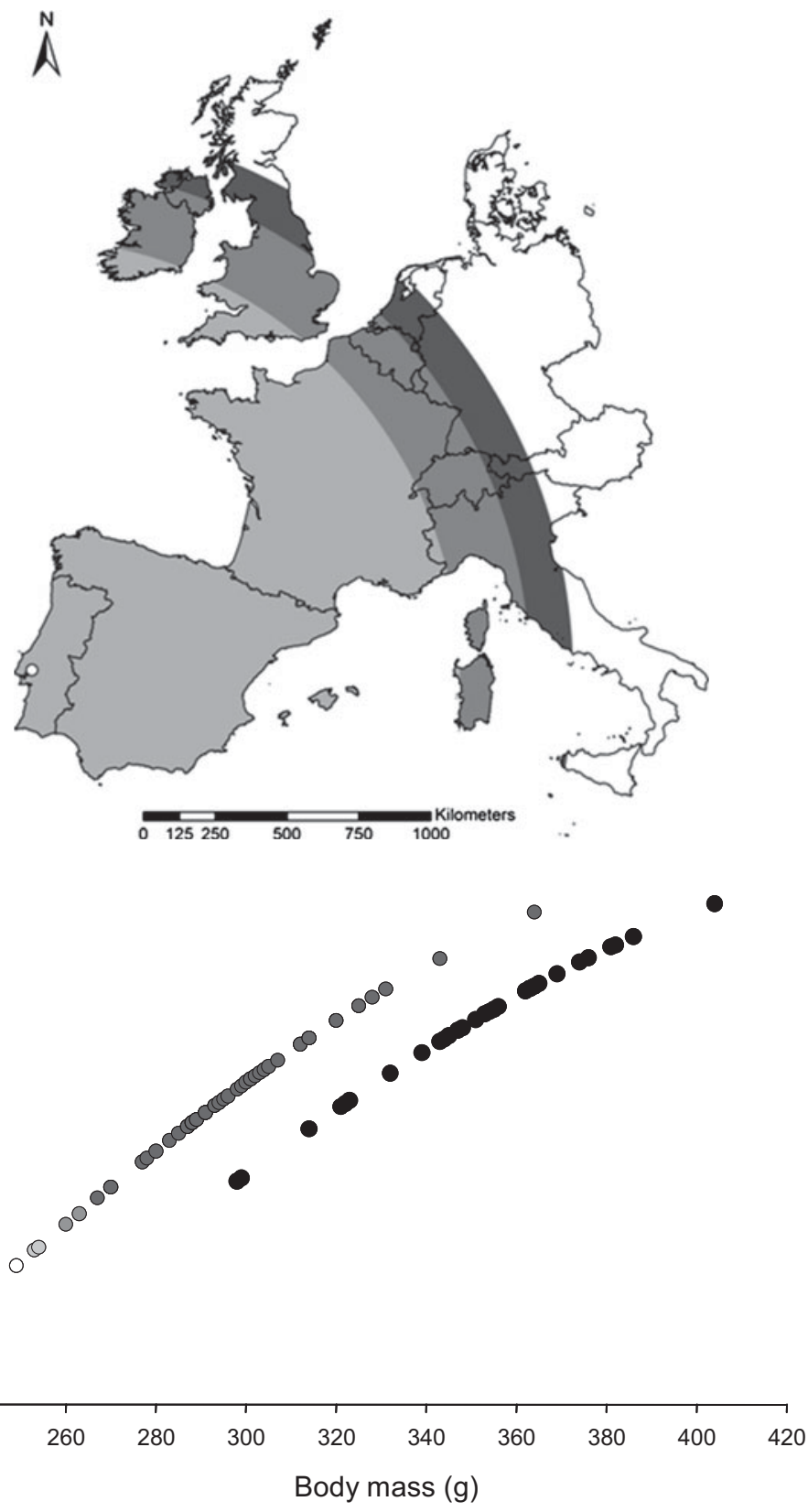

Figure 1. Predicted non-stop flight range for both sexes (graph) and male (map) Continental Black-tailed Godwits departing from a major Iberian stop-over site, the Tagus rice-fields (white circle). All females (black) are predicted to reach the breeding grounds in The Netherlands in one flight and flight ranges are therefore not mapped. The lightest male (open circle - not mapped) is predicted to fly only 1,348 km non-stop, whereas $98 \%$ of males (light grey), $94 \%$ (grey) and 90\% (dark grey) are predicted to reach the limit of shaded areas or beyond. 
which is insufficient to reach the core breeding locations in the Netherlands. However, this male was among the very early captures (weighed on 20 February) and possibly could have still been in the process of fattening. Even without additional fattening, this individual, as well as the following two lighter males, were predicted to reach the French coast of the English Channel, an area with suitable habitats for refuelling, and would not therefore have been likely to require a stop-over at traditional sites on the Atlantic coast of France.

\section{Discussion}

Of 84 adult godwits caught and weighed just prior to departure on the Tagus rice-fields, all except three males caught early in the departure period were predicted to be capable of reaching the breeding grounds in The Netherlands in a single flight. This evidence suggests that only a very small percentage of godwits require an obligatory second staging event in order to refuel during northward migration. Indeed, from a total of 478 individually colour-ringed godwits recorded in Iberia between 2005 and 2009, only $1.4 \% \pm 0.7( \pm \mathrm{SE})$ have on average, been subsequently recorded in France during spring of the same year (P. Lourenço unpubl. data). Although resighting effort on the French Atlantic coast is lower than in Iberia, these sites have been regularly surveyed for marked godwits since 2007. An alternative reason for a second staging event could be unfavourable winds experienced en route or conditions at the breeding grounds. However, it should be expected that godwits time their departure under favourable wind conditions and given the relatively short flight time to reach a suitable location in France (c.14 hours), similar wind conditions should be expected as these are correlated with those encountered up to 18 hours further along this same route (Shamoun-Baranes et al. 2010). Likewise, weather systems in the French Atlantic coast and the Wadden Sea are typically correlated, particularly in exceptionally cold springs (Hötker 2002). Hence, unfavourable environmental conditions would likely occur simultaneously at both locations.

As most godwits sampled just prior to departure were predicted to reach The Netherlands in one single flight, the apparent approximately two-week gap between departure from Iberia and median arrival in The Netherlands seems unlikely to be due to a second staging event on the Atlantic coast of France. The alternative explanation is that continental godwits may arrive in The Netherlands but avoid detection by surveys at that time of year, either because not all major Dutch arrival locations are covered (Kuijper et al. 2006), or because arriving birds are spread over many different locations in small flocks. Given that a considerable number of sightings of colour-ringed individuals on the breeding areas only occur after 20 March (Lourenço et al. 2011), this suggests that godwits might not go straight to territories upon arrival in the Netherlands, but rather use arrival locations prior to returning to territories, as do Icelandic godwits (Gunnarsson et al. 2006). Despite the individual variation in annual schedules (Lourenço et al. 2011), the number of individuals present at arrival sites scattered across the breeding grounds is likely to be a better descriptor of the use of sites by continental godwits during this period.

Since the 1980s, traditional staging sites along the French Atlantic coast and particularly in Morocco have become less important to godwits during northward migration (Kuijper et al. 2006, Gill et al. 2007) and currently host declining numbers (Zwarts et al. 2009). The causes of this reduced use of French staging sites during spring are unknown but might be linked to habitat change, e.g. conversion of wetlands into agricultural crops (Gill et al. 2007). Alternatively, this could be due to the reduced use of Moroccan sites and increased use of Iberian sites. Indeed, the Tagus and Sado rice-fields in Portugal and Extremadura and Coto de Doñana in Spain harbour c. $75 \%$ of the current population (Kuijper et al. 2006), although currently lacking legal protection. From a migratory perspective, making a single refuelling stop-over in Iberia rather than two (Morocco and France), is likely to reduce the total time of migration and therefore allow faster migration speed. The use of sites in Iberia appears to be linked to the development of large rice-field areas that form suitable habitat for refuelling godwits 
(Sánchez-Guzmán et al. 2007). If godwits depart from non-breeding sites (e.g. rice-fields of Rio Mansôa in Guinea-Bissau) in good condition (similar to departure from the Tagus) and fly directly to an Iberian staging site (e.g. Tagus rice-fields) instead of using the major traditional staging site in Morocco (Merja Zerga), only $500 \mathrm{~km}$ have to be added on to a total flight of c.3,200 km, a distance which would be within the range of most individuals (see graph in Figure 1 ).

The analysis of flight ranges for threatened migratory species can be used as a tool to predict the need and identity of possible locations of staging sites between the breeding and wintering areas. One potential such case is the Spoon-billed Sandpiper Eurynorhynchus pygmeus that breeds in north-east Russia and has core wintering locations in Myanmar, but staging sites are virtually unknown (Zöckler et al. 2010). Given that in both seasons individuals are caught (by scientists or hunters), the required parameterisation values are possible to obtain, making it feasible to model flight range and therefore map potential staging sites (N. Clark in litt. 2013).

\section{Conservation actions and recommendations}

Godwits staging in Iberian rice-fields are likely to fly directly to The Netherlands. We therefore believe that they will be present in that region (including Belgium) as early as late February and early March. It is likely that these individuals are scattered in small flocks and use many locations across the region, including some that might not be used for breeding, thus making it difficult to assess the total numbers present. Coordinated surveys and counts during this time of year would solve this issue and also indicate the location of key pre-breeding sites across the region. Some of these sites have already been identified, as large flocks are present in spring, e.g. Landje van Geijsel $\left(52^{\circ} 17^{\prime} \mathrm{N}, 4^{\circ} 55^{\prime} \mathrm{E}\right)$. This site regularly holds $1,000-3,000$ roosting godwits in early March but in very cold springs, during which fewer sites are suitable, it is known to hold 5,000-9,000 godwits (A. Duijnhouwer in litt. 2013). Given that turnover is likely to be high in such sites (but possible to estimate given the extensive marking and tracking programme currently developed for this population), knowing their location and extent of use would aid development of targeted conservation and management actions for these sites, which might serve a high proportion of individuals.

Vast numbers of godwits stage in Iberian rice-fields that currently lack any form of protection. These areas allow godwits to undertake a single stop-over in spring, instead of two (in Morocco and France), which was a likely strategy before the creation of the rice-fields. Given that rice production is subject to market fluctuations and that changes in this crop are known to affect birds (see review in Sutherland et al. 2012), the permanence of this habitat, or ecologically similar wetlands, should be secured, because natural wetlands in the region have diminished following agricultural and urban development (Dias 2009) and are currently used by fewer numbers of waders (e.g. Catry et al. 201I). The conservation of rice-fields and the restoration of the remaining natural wetlands in Iberia should be a priority as they are critical for a large number of wetland species. Although the creation of legislation for the protection and management of rice-fields has been identified as a high priority in the species action plan (Jensen et al. 2008), the Iberian rice-fields remain largely unprotected. Both Portugal and Spain have adopted this action plan and should act upon it, thus promoting the conservation of several other species (Lourenço and Piersma 2009). The inclusion of rice-fields that exist in the vicinity of already established protected areas (e.g. Tagus and Sado Nature Reserves in Portugal and Doñana National Park in Spain) as well as the inclusion of farming practices that make godwit conservation compatible with rice production (see Lourenço and Piersma 2008 for details) under Agri-Environmental Schemes (and CAP) would address the conservation issues faced by this population during spring migration.

Lastly, given that unpredictable weather events can force the use of secondary stop-over sites by waders in some years (Leyrer et al. 2009), the restoration of formerly used staging sites in France and Morocco should also be considered, as recommended in the species action 
plan (Jensen et al. 2008). These actions would secure the conservation of the migratory route of this rapidly declining population, as well as halting habitat loss and degradation for several other species currently using rice-fields (Elphick et al. 2010) and natural wetlands in the same areas.

\section{Acknowledgements}

Luisa Mendes, Ricardo J. Lopes, Sara Pardal and Afonso Rocha organised the ringing logistics and many other volunteers contributed during these catching sessions. Alexandre Leitão helped obtain the wing tracings and Veronica Mendez produced the map. Phil Battley, Eddy Wymenga, Nathan R. Senner and Catriona Morrison provided very useful comments to the manuscript.

\section{References}

Alerstam, T. and Lindström, A. (1990) Optimal bird migration: the relative importance of time, energy and safety. Pp. 331-351 in E. Gwinner, ed. Bird migration: Physiology and ecophysiology. Berlin: Springer-Verlag.

Alves, J. A., Lourenço, P. M., Piersma, T., Sutherland, W. J., and Gill, J. A. (2010) Population overlap and habitat segregation in wintering Black-tailed Godwits. Bird Study 57: 381-391.

Alves, J. A., Gunnarsson, T. G., Potts, P. M., Gélinaud, G., Sutherland, W. J. and Gill, J. A. (2012) Overtaking on migration: does longer distance migration always incur a penalty? Oikos 121: 464-470.

Atkinson, P. W., Baker, A. J., Bennett, K. A., Clark, N. A., Clark, J. A., Cole, K. B., Dekinga, A., Dey, A., Gillings, S., González, P. M., Kalasz, K., Minton, C. D. T., Newton, J., Niles, N. J., Piersma, T., Robinson, R. A. and Sitters, H. P. (2007) Rates of mass gain and energy deposition in red knot on their final spring staging site is both time- and condition dependent. J. Appl. Ecol. 44: 885-895.

Berthold, P. (1993) Bird migration: a general survey. Oxford: Oxford University Press.

Birdlife International (2004) Birds in Europe: Population estimates, trends and conservation status. Cambridge, UK: BirdLife International.

Catry, T., Alves, J. A., Andrade, J., Costa, H., Dias, M. P., Fernandes, P., Leal, A., Lourenço, P. M., Martins, R. C., Moniz, F., Pardal, S., Rocha, A., Santos, C. D.,
Encarnação, V. and Granaderiro, J. P. (2011) Long-term declines of wader populations at the Tagus estuary, Portugal: a response to global or local factors? Bird Conserv. Internatn. 21: 438-453.

Dias, S. (2009). Crescimento económico, sustentabilidade e desenvolvimento: o caso de Portugal. [Economic growth, sustainability and development: the case of Portugal]. PhD thesis. Lisbon: Universidade Nova de Lisboa. (In Portuguese).

Elphick, C. S., Taft, O. and Lourenço, P. M. (2010) Management of rice fields for birds during the non-growing season. Waterbirds 33 (sp1): 181-192.

Gill, J. A., Langston, H. W., Alves, J. A., Atkinson, P. W., Bocher, P., Vieira, N. C, Crockford, N. J., Gélinaud, G., Groen, N., Gunnarsson, T. G., Hayhow, B., Hooijmeijer, J., Kentie, R., Kleijn, D. Lourenço, P. M., Masero, J. A., Meunier, F., Potts, P. M., Roodbergen, M., Schekkerman, H., Schröder, J. Wymenga, E. and Piersma, T. (2007) Contrasting trends in two Black-tailed Godwit populations: a review of causes and recommendations. Wader Study Group Bull. II4: 43-50.

Gunnarsson, T. G., Gill, J. A., Atkinson, P. W., Gélinaud, G., Potts, P. M., Croger, R. E., Gudmundsson, A. G., Appleton, G. F. and Sutherland, W. J. (2006) Populationscale drivers of individual arrival times in migratory birds. J. Anim. Ecol. 75: 1119-1127.

Hötker, H. (2002) Arrival of Pied Avocets Recurvirostra avosetta at the breeding site: 
effects of winter quarters and consequences for reproductive success. Ardea 90: $379-387$.

Jensen, F. P., Béchet, A. and Wymenga, E. (2008) International Single Species Action Plan for the conservation of the Black-tailed Godwit Limosa l. limosa and L. l. islandica. Bonn, Germany: AEWA. (AEWA Technical Series No. 37).

Kuiper, D. P. J., Wymenga, E., Van Der Kamp, J. and Tanger, D. (2006) Wintering areas and spring migration of the Blacktailed Godwit. Bottlenecks and protection along the migration route. Veenwouden, The Netherlands: Altenburg and Wymenga Ecologisch Onderzoek. (AandW Report No. 820).

Leyrer, J., Bocher, P., Robin, F., Delaporte, P., Goulevent, C., Joyeux, E., Meunier, F. and Piersma, T. (2009) Northward migration of Afro-Siberian knots Calidris canutus canutus: high variability in red knot numbers visiting staging sites on the French Atlantic coast, 1979-2009. Wader Study Group Bull. 116: 145-151.

Lourenço, P. M. and Piersma, T. (2008) Stopover ecology of Black-tailed Godwits Limosa limosa limosa in Portuguese rice fields: a guide on where to feed in winter. Bird Study 55: 194-202.

Lourenço, P. M. and Piersma, T. (2009) Waterbird densities in south European rice fields as a function of rice management. Ibis 151: 196-199.

Lourenço, P. M., Kentie, R., Schroeder, J., Alves, J. A., Groen, N. M., Hooijmeijer, J. C. E.W. and Piersma, T. (2010) Phenology, stop-over dynamics and population size of migrating black-tailed godwits Limosa limosa limosa at a key staging area, the Tejo and Sado rice plantations. Ardea 98: 35-42.

Lourenço, P. M., Kentie, R., Schroeder, J., Groen, N. M., Hooijmeijer, J. C. E. W. and Piersma, T. (2011) Repeatable timing of northward departure, arrival and breeding in Black-tailed Godwits Limosa l. limosa, but no domino effects. J. Ornithol. 152: 1023-1032.

Moreau, R. E. (1972) The PalaearcticAfrican bird migration systems. New York: Academic Press.
Pennycuick, C. J. (2008) Modelling the flying bird. Oxford: Academic Press.

Piersma, T. (1987) Hink, stap of sprong? Reisbeperkingen van arctische steltlopers door voedselzoeken, vetopbouw en vliegsnelheid [Hop, skip or jump? Constraints on migration of arctic waders by feeding, fattening and flight speed] Limosa 60: 185-191. (In Dutch).

Sánchez-Guzmán, J. M., Morán, M., Masero, J. A., Corbacho, C., Costillo, E., Villegas, A. and Santiago-Quesada, F. (2007) Identifying new buffer areas for conserving waterbirds in the Mediterranean basin: the importance of the rice fields in Extremadura, Spain. Biodiv. Conserv. 16: 3333-3344.

Schroder, J., Lourenço, P. M., van der Velde, M., Hooijmeijer, J. C. E. W., Both, C. and Piersma, T. (2008) Sexual dimorphism in plumage and size in Black-tailed Godwits Limosa limosa limosa. Ardea 96: 1-13.

Shamoun-Baranes, J., Leyrer, J., van Loom, E., Bocher, P., Robin, F., Meunier, F. and Piersma, T. (2010) Stochastic atmospheric assistance and the use of emergency staging sites by migrants. Proc. R. Soc. Lond. B. 277: 1505-1511.

Sutherland, W. J., Alves, J. A., Amano, T., Chang, C. H., Davidson, N. C., Finlayson, C. M., Gill, J. A., Gill, R. E. Jr., González, P. M., Gunnarsson, T. G., Kleijn, D., Spray, C. J., Székely, T. and Thompson, D. B. A. (2012) A horizon scanning assessment of current and potential future threats to migratory shorebirds. Ibis 154: 663-679.

Wymenga, E. and Sikkema, M. (2011) Steltlopers op slaapplaatsen in Fryslân in 2008. Twirre 21: 22-35.

Zöckler, C., Syroechkovskiy, E. E. and Atkinson, P. W. (2010) Rapid and continued population decline in the Spoon-billed Sandpiper Eurynorhynchus pygmeus indicates imminent extinction unless conservation action is taken. Bird Conserv. Internatn. 20: 95-111.

Zwarts, L., Bijlsma, R. G., van der Kamp, J. and Wymenga, E. (2009) Living on the edge: Wetlands and birds in a changing Sahel. Zeist, The Netherlands: KNNV Publishing. 
JOSÉ A. ALVES*

School of Biological Sciences, University of East Anglia, Norwich Research Park, Norwich, NR4 7TJ, UK.

\section{PEDRO M. LOURENÇO}

Museu Nacional de História Natural, Universidade de Lisboa, Rua da Escola Politécnica 58, 1250-102 Lisboa, Portugal.

*Author for correspondence; email: j.alves@uea.ac.uk

Received 4 October 2012; revision accepted 16 April 2013; Published online 18 September 2013 